\title{
Land reform in South Africa and the colonial present
}

This paper develops Derek Gregory's concept of the 'colonial present' by demonstrating how the colonial present in rural South Africa in general and around land reform in particular has conditioned land reform outcomes. My development of the concept departs from Gregory's in two key respects. I argue first that, by viewing it in relation to the geopolitics of capitalism, it can be applied to places beyond the immediate influence of U.S. military power; and, second, that social forces which might begin to undermine the colonial present should be examined. My empirical materials draw upon primary research on the emergence of government-sponsored partnerships between restitution beneficiaries and agribusinesses in northern Limpopo. I use the materials to argue that partnerships have emerged given white farmers' near-monopoly on skills and the persistent power of traditional leaders, two features of South Africa's colonial past whose importance today is suggestive of a colonial present.

Keywords: land reform, restitution, colonialism, South Africa, Levubu, Venda 


\section{Introduction}

Derek Gregory’s The Colonial Present (2004) is an analysis of war, terror, and violence in Afghanistan, Palestine and Iraq. He uses a wide range of materials to argue that 'the capacities that inhere within the colonial past are routinely reaffirmed and reactivated in the colonial present' (p.7). Referring to some of the politics and geographical dimensions of land reform in South Africa, I suggest that land reform outcomes have been fundamentally affected by relations of a thoroughly colonial type. South Africa is conventionally viewed as a 'postcolonial' place; in contrast to that view, I call attention to the colonial present in South Africa. I argue that it has two dimensions: first, white farmers’ near-monopoly on technical and entrepreneurial agricultural skills; second, the persistent power of those traditional leaders whose capacity the apartheid regime tried to elevate for its own purposes. I draw upon a wide range of literature on South Africa as well as primary research conducted in northern Limpopo province to illustrate how the colonial present has been germane to the emergence of certain land reform outcomes specifically, the government-sponsored emergence of partnerships between land reform beneficiaries and agribusinesses. My interest is on the way in which the government has grappled with, and struggled to overcome, enduring and reactivated colonial relations; my focus is on outcomes of South Africa's colonial present, rather than the processes through which particular agents actively construct it.

\section{Understanding the colonial present}

Gregory focuses on how the U.S. and its allies pursue domination via discursive practices, binaries, concepts of 'modernity' and 'tradition', narratives about territorial logics; in short, and drawing parallels with Said’s (1978) concept of Orientalism, via ‘imaginative geographies’. The U.S. constructs an 'architecture of enmity', which 'turn[s] on the cultural construction of their

opponents [...] as outsiders’ (Gregory 2004: 28). Elaborate techniques have been deployed, such as a 'cartographic performance’, which discursively justified the invasion of Afghanistan by 
locating the diffuse $\mathrm{Al}$ Qaeda network in Afghanistan. The enemy was thereby located in a constructed field of battle (pp. 49-56), even though, and as Ettlinger and Bosco (2004) have theorized, 'networks such as Al-Qaeda are constituted by a socio-cultural fabric that is intangible and cannot be located at fixed coordinates for either bombing or surveillance' (pp. 254-55). To talk of a colonial present, then, is not to suggest that the U.S. or Britain are actively establishing colonies in Iraq, even though their military presence entails seizing land and establishing bases. Rather, it is to highlight the endurance, persistence or reactivation of particular colonial-style relations, which Harris (2004) has stressed should be understood as encompassing violence, dispossession, occupation and subjugation (as understood, for example, by Fanon 1963) as well as discourses and knowledge(s) (as theorized by Said).

Gregory's point in all of this, at least as I understand it, is to emphasize the similarities and symmetries between the manner in which material and discursive power was practiced by, say, Britain or France in the late nineteenth century and by the U.S. today. It is to call attention to the endurance of colonial-style practices and relations. Although it is unclear whether Gregory intended the colonial present concept to be applied to other contexts, I want to demonstrate that it does have wider applicability. Towards achieving this goal, however, I argue it is necessary - and possible - to re-theorize why the colonial present exists.

In a telling statement, Gregory argues that, 'the war on terror is an attempt to establish a new global narrative in which the power to narrate is vested in a particular constellation of power and knowledge within the United States of America' (p.16). There is a hint of state-centric thinking here; that is, Gregory leaves the reader with a sense that the colonial present is not only pursued by states in the midst of 'realist' geopolitics, but also that states and their geopolitical maneuvrings are the driving forces behind the existence of the colonial present. In Gregory's view, places will only be caught up in a colonial present if they are experiencing colonial-style techniques of domination practiced by the U.S. state and its war machine. 
Whereas Gregory tends to see the geopolitical maneuvrings of states behind the reaffirming and reactivating of colonial relations, I find David Harvey’s view of geopolitics (1985), imperialism (Harvey 2003) and neoliberalism (Harvey 2005) a useful alternative. Harvey's focus is on the geopolitics of capitalism, not states per se. His focus is on the territorial battles entailed by the necessarily geographic character of accumulation. He stresses the central role played by the U.S. government but theorizes that the driving force behind neoliberalism, and by extension U.S. military activities in Afghanistan and Iraq, is a 'political project to re-establish the conditions for capital accumulation and to restore the power of economic elites' (2005: 19; emphasis in original). The key element is accumulation. Thus, outcomes such as the invasion of Iraq are part of attempts by the U.S. elite to 'redefine the global and domestic order to its own advantage’ (2005: 189).

I want to suggest that embracing Harvey's view of the driving forces behind U.S. military intervention makes it possible to re-imagine the geography of the colonial present. If colonialstyle relations and practices endure or are reactivated because they suit the political-economic demands of accumulation, rather than particular states, then it becomes possible to imagine the colonial present operating in places outside the so-called Middle East; that is, in places that play little, if any, role in the 'war on [/of] terror'. As I demonstrate, the colonial present can be theorized as existing and operating in a place such as South Africa. In contrast to the prominence Gregory affords aspects such as the application of particular technologies or discursive practices of domination, I emphasize the material dimensions of colonial-style relations in the light of the accumulation process as it unfolds in a geographic context. My focus is on outcomes of South Africa’s land reform process.

\section{Land reform in South Africa}

A recurring theme in the recent geography literature involves questions of the unequal distribution of land, of social movements of the landless, of state- or market-led land reform 
(Benjaminsen et al 2006; Bobrow-Strain 2004; Wolford 2003, 2005; Ramutsindela 2002). Such work by geographers reflects the social, economic and political significance of 'land questions' in various settings around the world. One such place is South Africa. It is in the midst of a land reform program intended to undo a racially skewed distribution of land: the country's 45,000 or so white farmers owned 82.2m hectares (67 per cent) of South Africa’s land area in 1996 (Walker 2006: 145). Land reform aims to redistribute 30 per cent of commercial (and almost entirely white-owned) agricultural land by 2014 (Kepe and Cousins 2000; Ntsebeza and Hall 2006). According to a recent estimate, around 3.5 million hectares (or four percent) of agricultural land had been redistributed by February 2005 (Hall 2006). ${ }^{\text {i }}$

A key pillar of land reform is 'restitution', via which individuals or groups of people dispossessed of rights in land by racially discriminatory laws since 1913 can claim back particular pieces of land (see Hall 2003, 2004). The pace of delivery in restitution has been far from impressive, something which has attracted criticism from land reform advocates and analysts (e.g. Lahiff 2005). Further criticism might emerge as a response to how the government has begun to settle some high-profile restitution claims. In particular, some claims on highly developed agricultural land have been completed by forcing restitution beneficiaries to enter into partnerships with white-owned agribusinesses (Mayson 2003; Shaker 2003). Shaker (2003) examined the terms according to which a partnership took shape on a former homeland citrus estate, Zebediela. The farm was 'restructured' i.e. privatized, and then returned to its rightful owners, the Bjathladi land claims community. However, the government only agreed to return the land under a highly restrictive arrangement via which the Bjathladi beneficiaries would have to enter into agreement with a 'strategic partner', South African Farm Management (SAFM). The Zebediela arrangement, which hinted at the rising influence of agribusinesses within the domain of land reform, informed the government's approach to restitution in Levubu, and area of approximately 10,000 hectares of sub-tropical land around the Luvuvhu River on the southern piedmont of the Soutpansberg Mountains (see Figure One). Roughly 200 white farmers in 
Levubu grow avocados, macadamia nuts, mangoes and bananas for domestic consumption and export. The government has settled restitution claims on Levubu and transferred title deeds to seven groups - formally, although tenuously, 'communities' - of beneficiaries constituted by descendants of close to 10,000 people forcibly removed from the area in the late 1930s by the whites-only South African government.

\section{[INSERT FIGURE ONE HERE]}

Although the Levubu beneficiaries will own the land, they will not have full control over how it will be used. Rather, the government has deemed that, for at least the next fifteen years, the beneficiaries must operate the land in partnership with white-owned agribusinesses with which they will form joint venture companies. The beneficiaries are not allowed to re-settle the land, nor use it as they see fit; the land will be formally theirs, they will receive a revenue stream from it, but the government is insisting that the land is managed in a way that it prefers; i.e., commercially and in partnership with experienced and white partners (Fraser 2007). The arrangement is uneven. The agribusiness partners could use some of their other businesses upstream or downstream of the actual farming operations either to supply the joint venture companies at above-market rates, or to sell outputs to their factories or marketing companies at below-market rates. Another concern is that the white-owned agribusinesses will be more interested in short rather than long-term gain and hence will be prone to discourage sufficient investment in the land. The onus will be on the beneficiaries to monitor the activities of their partners and to ensure that adequate investment occurs rather than a gradual deterioration in the quality of their land. My interest is in understanding why and how white-owned agribusinesses are beginning to occupy such a prominent position in South Africa’s land reform program.

\section{South Africa's colonial past}


South Africa's colonial past is an inescapable context for the contemporary land question. European settlers backed up by whites-only governments seized vast areas of land from Africans before and subsequent to the landmark 1913 Natives’ Land Act, the historical cut-off point for claims for restitution of land rights. Some of that land was farmed by an emerging African peasantry producing for new markets associated with mining (Bundy 1979). Dispossession destroyed the emerging African peasantry. Others had their land taken and, compelled to pay taxes in cash, were forced to find wage labor in the mining sector (Callinicos 1987). Unlike in numerous other colonial settings, Africans dispossessed of land and thrust into wage labor in South Africa were largely prevented from settling permanently in the cities. Instead, the colonial state established an archipelago of 'Native Reserves' (later 'Homelands'), totaling around thirteen percent of the land area by 1936, from which Africans migrated to the cities to work (Beinart 2001). The whites-only state controlled Africans in the native reserves via a system of 'imperial rule’ (Ashforth 1997).

Following the election in 1948 of the Afrikaner nationalist party, the National Party, the apartheid-era South African polity then developed into a 'bifurcated state' (Mamdani 1996) in which traditional leaders - Mamdani’s (1996) ‘decentralised despots' - in the Homeland areas were formally allocated far-reaching powers with respect to land, labor, and gender relations. The policies of 'grand apartheid’ (Crais 2006: 721) pursued Africans' subjection indirectly via traditional leaders. Thus, and as Ashforth (1997: 109) has noted, 'when it has come to questions of maintaining “order” and dispensing coercion Chiefs have performed crucial roles, symbolic and practical: suppressing resistance while distributing scarce resources’. But the decentralization of power to intermediaries in the Homelands recognized only to a limited extent the sovereignty of traditional leaders within their 'invented' (Crais 2006) domains; the whites-only nation-state was the 'supreme chief' (Mamdani 1996: 101) in the reserves. Nevertheless, 'Whether it was about attaining a plot of land, getting a work permit or an old-age pension, or obtaining access to justice, the chief had by legislation been made into the sole portal to government' (Oomen 2005: 
20). Establishing the Homeland areas entailed thousands of forced removals, through which as many as 3.5 million people were displaced and located in one Homeland area or another (Platzky and Walker 1985). Many claims for restitution in urban and rural areas refer to this period of dispossession. However, by no means all of the 14 million or so people (Walker 2003) still living in what are now the former homeland areas, and therefore still living under the influence of traditional leaders and their allies, are in line for restitution.

One final dimension of South Africa's colonial past to consider here is the fact that the pre- and apartheid-era South African polity promoted a whites-only commercial agricultural sector, the advancement of which was a major reason for dispossession and forced removals. South Africa's white farmers were major beneficiaries of colonialism, not just because the sector developed on land seized from Africans: rather, and especially under apartheid governments, the state sought to develop agriculture according to a model in which large-scale farming would draw heavily on state subsidies, protectionist measures, and use cheap African labor (Bernstein 1996; Greenberg 2003).The model lurched into crisis in the late 1970s and early 1980s as lending institutions leaned on the National Party to open its market and reduce subsidies. Consequently, South African agriculture underwent a process of deregulation, which was largely completed in 1996 by the country's first democratic government. As in other places in which agriculture has undergone deregulation, agribusinesses have been empowered in South Africa and, as I shall now begin to discuss in more detail, are now well-positioned to gain in a post-land reform environment.

\section{South Africa's colonial present}

My interest is in explaining how a colonial present has affected land reform. The first dimension refers to white farmers' near-monopoly on technical and entrepreneurial skills needed for commercial agriculture. Whites were the only legitimate commercial farmers under apartheid. Not surprisingly, historically disadvantaged groups often lack the technical, marketing, legal, or 
financial skills needed to farm land commercially. Groups representing emerging (mostly African) farmers such as the National Emergent Red Meat Producers' Organisation have identified skills shortages among their members as a major constraint to growth (Business Day, $6^{\text {th }}$ April 2006) and have called on the government to step up its efforts to attract young black people into agriculture (Business Day, $5^{\text {th }}$ September 2005). Of course, the skills question in agriculture reflects a broader problem in South Africa. A skills shortage among South Africa's historically disadvantaged population has caused problems for state departments, national and local government (Lodge 2005), as well as limiting growth in particular economic sectors, such as call centers (Benner 2006). There are multiple causes, including ‘Bantu’ education policies in the apartheid-era, under-resourced schools in the contemporary period, and an inadequate public and private sector skills training program. There are signs that the state is addressing the skills problem: a Sector Education and Training Authorities (SETA) program has begun to upgrade skills. However, it did not begin soon enough after 1994.

Thus, in the absence of concerted efforts to address the problem, white farmers continue to enjoy a near-monopoly on technical and entrepreneurial agricultural skills. Features of the colonial past - in this case white farmers' privileged position - endure into the present.

A second dimension of the colonial present has to do with another group of actors whose power has endured from the colonial past into the present: traditional leaders, as they were during the colonial / apartheid era, remain powerful in South Africa, if not necessarily at the national level then certainly in numerous rural areas in which traditional leaders retain rights to administer land. Their continued influence over people's lives is an irrefutable reality in the former homeland areas of South Africa. It is, moreover, an extraordinary outcome, a 'constitutional contradiction' (Rangan and Gilmartin 2002), that the post-apartheid polity protects the institution of traditional authority even though the democratic Bill of Rights enshrines governance by elected representatives (Ntsebeza 2003). Rather than tackling their power, recent legislation such 
as the Traditional Leadership and Governance Framework Amendment Act 2003 illustrates the extent to which the government has actually strengthened their position.

Perhaps not surprisingly, given their extensive powers in the colonial and apartheid era, traditional leaders have become prominent actors in the land reform process. There is firm evidence in the literature (e.g. Claassens 2001; Cousins 2006; Hall 2003; Mathis 2007) that traditional leaders and / or their allies actively strive to ensure that (at the very least) land reform does not undermine their social status, or (perhaps more commonly) ensure they receive a significant share of the benefits. A necessary caveat here is that traditional leaders are by no means influential actors in all land reform cases; few would have been involved in the almost 50,000 restitution claims for urban land, 'often involving individual families’ (Hall 2003: 25). ${ }^{\text {ii }}$ Equally, and as Deborah James (2005) has noted, there are other individuals within groups of land reform beneficiaries who seek out personal gains at the expense of others.

Attention to restitution is particularly helpful when thinking about the power of traditional leaders. Some traditional leaders in some areas have actually been empowered by the design of the restitution program as well as by how the government has implemented it. In terms of design, the restitution program provides for 'communities' of claimants to seek restitution of land rights. Ruth Hall (2003: 16) claims this has 'sparked struggles over rights to land'; work by Everingham and Jannecke (2006) substantiates Hall's claim. At issue are the ways in which postrestitution rights are defined, defended, or contested by leaders of Communal Property Associations, traditional leaders or other groups such as civic organizations. Given that many, if not all, traditional leaders believe that land under claim for restitution should be returned to them, it is hardly surprising that some traditional leaders have 'contested the authority of elected trustees' and 'captured the benefits' for themselves (Cousins 2006: 237). If the land is reverted back to communal tenure, then traditional leaders will have the power to allocate it as they see fit; a far-reaching power but not something that restitution is supposed to deliver. 
Besides how restitution has been designed, its implementation has not ensured that the leaders of groups of land reform beneficiaries are democratically elected rather than constituted or appointed by traditional leaders. Limited resources would appear to be one cause of the state's inadequate response to the challenge of ensuring that land reform does not benefit elite leaders, or that beneficiaries are equally represented in 'community' organizations. Properly ensuring that communities claiming land were democratically represented would have required officials to spend much more time engaging with all of the beneficiaries, for example by running workshops with them to encourage participation.

But it is worth noting here that traditional leaders also occupy positions of power and influence because they have an edge over others by virtue of their involvement in the former homeland administrations. For example, of the five main leaders of one group of claimants in northern Limpopo that I researched in early 2005, three had worked for the former Venda homeland government. Those experiences required and provided a level of education and knowledge of bureaucratic procedures not shared by the majority of their fellow claimants, which helped in the leaders' attempts to lead the restitution claim and control what happens to any income from the land.

Thus, in areas of South Africa in which traditional leaders or their allies exert their typically undemocratic influence, social life in nominally postcolonial South Africa is akin to a colonial present. The institution of traditional authority - something which was formalized and promoted in the colonial period - is still a central feature of social life for millions of South Africans.

\section{Accumulation and the colonial present in South Africa}

Why, then, has the government not eliminated hereditary traditional authority rule; and why has the skills shortage among historically disadvantaged groups not been sufficiently addressed? In short, why is there a colonial present in South Africa? I suggest that both dimensions of the 
colonial present should be viewed in the light of South Africa's position relative to the accumulation process, and understood on a world scale. To rehearse the arguments of numerous scholars writing about neoliberalism in South Africa (e.g. Bond 2000; Carmody 2002; Peet 2002), the South African government has pursued an array of neoliberal policies which seek to keep inflation in check and achieve a positive balance of payments. The objective of policies such as water privatization, deregulation, 'efficiency drives' and restructuring of state assets is to (re)create the conditions for accumulation and secure a more advantageous position for South Africa in the international division of labor. The disciplining force of meeting inflation targets helps to explain why the government has been reluctant to borrow and then heavily invest in upgrading skills. Furthermore, neoliberalism is germane to understanding other dimensions of white farmers’ privileged position. The government agreed in the early 1990s to pursue land reform along the lines of a neoliberal-style model. Thus, and reflecting various tensions and social forces in the early 1990s - such as the central position of white farmers in the Afrikaner national imaginary, World Bank advice to the African National Congress (ANC) during negotiations to end apartheid, and the ANC's determination to establish a cross-class alliance with South African capital - the ANC committed itself to a 'willing-seller, willing-buyer principle', which means land can only be acquired from landowners who agree to sell (Walker 2005). South Africa’s 'market fundamentalism’ (Lahiff 2005: 4) in this regard reflects neoliberal approaches to land reform in other places (Bobrow-Strain 2004; Borras 2003; Moyo and Yeros 2005). As Lahiff (2005) has noted, then, white farmers were effectively granted a 'veto' over land reform. Thus, although the first democratic Constitution provided for land reform, it protected the existing landowners; it has, indeed, a strongly colonial character. The Constitution may have transformed formal political rights but it protected the property rights of white beneficiaries of colonialism, including white farmers. Perhaps unsurprisingly, it appears that the main beneficiaries of the state's neoliberal turn have been those who already enjoyed material privileges, that is, capital in general and the country's middle class whites: although there have 
been some new, high-profile black entrants to the capitalist class, economic power remains largely concentrated among whites. A consequence of the South African government's neoliberal stance and the Constitution, therefore, is that the degree of social and material change has not been too transformative.

It should be noted here that neither the government's inattention to the question of skills nor the white farmers' veto over land reform would matter as much if the government was not so intent on ensuring that redistributed land is used for commercial purposes. As Gillian Hart (2002) has argued, for example, land reform could have followed the example of some East Asian countries by delivering land for subsistence purposes to the working class to supplement low wages. However, in the development of its current (revised) redistribution program, Land Redistribution for Agricultural Development, and in its approach to settling restitution claims, the government has stressed that redistributed land should be used for commercial, rather than subsistence, purposes (Jacobs et al 2003). The outcome of the government's stance with respect to skills and its emphasis on commercial agriculture is a heavy reliance on white farmers.

With regards to the position of traditional leaders, it is far from clear why the government is 'casting its weight' with them (Crais 2006: 735). Ntsebeza (2003) suggests that the ANC's urban bias, its pragmatic outlook, and ‘broad-based organisation, with a diversity of opinions’ combine in such a way that the ANC is 'under no pressure to resolve the issue of democracy in rural areas' (p.76). Others suggest that accumulation, class struggle, and South Africa's position relative to the geopolitics of capitalism matter. Clifton Crais' (2006: 734) hypothesis, for example, is that traditional leaders are a useful bulwark to protect the government from protests against its neoliberal stance and the slow pace of transformation. The dynamics and geopolitics of capitalism, which make it difficult - if not impossible - for the South African government to pursue anything other than a neoliberal path, become implicated in the persistent power of traditional leaders. In effect, traditional leaders occupy a similar, privileged position as a conservative force in the democratic state as they did during the colonial / apartheid era. 
The colonial present and the Levubu partnership approach

I now draw on some materials regarding the restitution of land rights in the Levubu area of Limpopo province, and with particular reference to the government's decision to opt for partnerships, to bring to light how the colonial present affects restitution outcomes. As mentioned earlier, although the returned land could have been directly transferred, thereby allowing the beneficiaries to decide what should be done with it, this has not occurred. What, then, did the government see as the benefits of having partnerships take shape?

Reflecting the skills problem, the first dimension of the colonial present, officials working with the Limpopo Land Claims Commission (and closely involved in the Levubu case) viewed partnerships as a way to deal with the beneficiaries' lack of technical and entrepreneurial skills. Officials drew upon the experience of early restitution 'failures' (cases in which restitution beneficiaries failed to operate transferred land) elsewhere in Limpopo. The collapse of agricultural production at Mamathola, for example, drew attention to the risks of directly transferring the land and relying on public sector post-settlement support, the deficiencies or total absence of which 'has led to serious problems' (Hall 2003: 18). Although many of the beneficiaries in Levubu practice subsistence agriculture and some even operate commercial farms, the government was convinced that the beneficiaries’ aggregate technical and entrepreneurial skills were far removed from the range of skills (such as applying pesticides, buying supplies, managing export contracts, etc.) practiced by the white horticultural farmers in Levubu. Partnerships were therefore viewed by government officials as a way to deal with the skills problem.

Crucially, the government's determination to establish partnerships has played into the hands of some white farming interests for whom collaboration with the government and restitution beneficiaries via the partnership approach had a compelling logic. One group of white farmers in Levubu with investments up and downstream of farming was especially keen to enter 
into agreements that would provide secure access to a supply of raw materials to their factories as well as a market for their tree nurseries (Fraser 2007). They will share any farm-based profits and pay the beneficiaries an annual lease. A skills transfer plan is also expected to equip some among the beneficiaries with the requisite technical and entrepreneurial skills to assume full control over the farms at the end of the lease period. The white partners will therefore have plenty of time over the fifteen-year period of the agreement to recoup earlier investments in juicing and nut-drying factories. By virtue of their knowledge and managerial status, moreover, they will be well positioned to take advantage of the beneficiaries. They will have expertise that they might use to deceive the beneficiaries, for example by suggesting that investments in replacing fruit trees are not needed. The relationship established in the partnership appears lop-sided. The beneficiaries may become heavily dependent on their white agribusiness partners.

White farming interests have certainly played a role in the forging of partnerships; likewise, the government has been determined to see them emerge. But there also is evidence to suggest that traditional leaders played a role in moving the wider group of beneficiaries towards partnerships. Based on my research with one group of people claiming back their land in Levubu, I now want to suggest that traditional leaders have been instrumental in laying the ground for the partnership approach. At issue is the degree to which the beneficiaries acquiesced with the government’s partnership approach.

The focus here is on the Ravele group of beneficiaries. Their ancestors were almost entirely dispossessed of land rights in what is now known as Levubu in 1938; 'almost', that is, because, although all of the people were forced to move from Levubu to Mauluma and other areas of what eventually became the Venda homeland, the traditional leader’s family retained access to some ancestral graves. In 'compensation' for removal from their land, those living in the Ravele area were forced to move to Beaconsfield, Baobab, and Mapila farms in the Nzhelele valley, 20km northwest of the old Mauluma. The 'compensation' farms were of inferior quality. For example, whereas the original Mauluma could expect a minimum of $1,000 \mathrm{~mm}$ of annual 
rainfall and had ample grazing and cultivable land, annual rainfall totals in the new Mauluma are half or less and the soil and grazing land are greatly inferior. According to those in (the new) Mauluma who can recall first arriving there, life was much harder. A member of the Ravele LCC described the change:

Before we were moved, we had goats, sheep, cattle, even horses, but many died on the way here. We had no more horses after that. Stocks of mealie-meal and other possessions were lost...This [new] place is too dry, too hot...Many people passed away...It was very bitter for them. You know, we were told, "look how big is the farm we are giving you compared to your land now”. But the quality of the land was not as good. Living is too hard here. (Personal Interview with Respondent \# 20, August 2004).

The Ravele traditional leader, F.N. Ravele (1926-1999), who was a leading member of the 'independent' Venda Homeland government (Lahiff 2000), led a claim for restitution of the Ravele land in 1998 under the terms of the Restitution of Land Rights Act, 1994. He appointed some of his closest allies to leadership positions in the Ravele Land Claims Committee. These committee members - all of whom were men - have since been joined by allies of the present traditional leader, but they have retained significant influence over decision-making (Personal interviews with numerous members of Ravele Land Claims Committee, February-April 2005). Thus, the Ravele beneficiaries have been led by allies of the former and current traditional leader rather than a democratically-elected leadership. Few among the beneficiaries have had any opportunity to do anything about the restitution claim as the leadership has retained tight control over information and decision-making.

I argue that the Ravele leaders have played a significant role in pushing for partnerships, particularly among their fellow Ravele beneficiaries. In particular, the leadership cultivated enthusiasm for and acquiescence towards partnerships. That the beneficiaries as a whole accepted 
the partnership proposals, despite the obvious risks, therefore reflects the advice of an undemocratic leadership installed by one traditional leader and then sponsored by his son. A not insignificant factor playing into the leaders' hands was that the registered beneficiaries were scattered throughout the former Venda homeland, which made attending meetings held in Mauluma difficult (see Figure Two). Also worth noting here is the large number of Ravele beneficiaries who have migrated from Mauluma to Gauteng to find work and who are therefore not around to stay involved in decision-making in Mauluma. In other words, contingent conditions allowed the traditional leaders to prevail. If there had been a stronger interest among the Ravele people in the restoration of the land as a material matter, then there might have been stronger demands for a more open decision-making process. I suggest that these conditions merged with the community form of restitution, played into the leadership’s hands, and helped move the beneficiaries towards accepting partnerships.

\section{[INSERT FIGURE TWO HERE]}

\section{Conclusion: A stable colonial present?}

I have argued that crucial considerations in the emergence of partnerships in Levubu are the nearmonopoly on the technical and entrepreneurial skills appropriate to commercial farming which white farmers enjoy and the influence of traditional leaders in cultivating the beneficiaries’ acquiescence with the government's partnership approach. The colonial present has affected land reform outcomes. The question I should like to address now is whether the colonial present is stable; that is, are there forces that might begin to undermine the colonial present in South Africa? Gregory's view of the colonial present leaves one with a strong sense of its embeddedness in the politics of today, its necessity to the practices of U.S. power. There are few glimmers of hope in The Colonial Present, which is perhaps understandable given the nature of the material on detentions, air strikes, murder in Baghdad, or occupation in Gaza with which he dealt. I suggest an alternative imaginary is needed for the colonial present concept to remain in the human 
geography lexicon. A more hopeful view of the future is integral to Doreen Massey’s (2005)

conceptualization of space. Like Gregory, Massey bases her understanding of time and space on a non-teleological view of the future, which in turn relies on accepting the possibility of heterogeneity and difference (literally) making a difference - but which also anticipates unexpected, or open, futures. In the spirit of anticipating openness, it is worth asking whether the colonial present will endure.

With regards to addressing the skills question in South Africa, a response might be for the state to intervene more heavily than it has hitherto. Indeed, in a recent discussion of the South African state, Bill Freund (2006) has suggested that the prospect for a developmental state to emerge in South Africa rests on 'overcoming its historic backwardness in terms of education and skills’ (p.6). Unwrapping the colonial present with respect to skills in agriculture and setting the scene for a more just transformation in agrarian relations depends to a great extent on approaching the skills issue with fresh ideas. A major government push is needed to reduce white farmers' monopoly of skills suitable for commercial agriculture. Perhaps a more extensive and radical training program than the government's current Sector Education and Training Authorities will begin to emerge. In the absence of such a push, however, it seems likely that the government's ambitions for what land reform can achieve will continue to rely on white farmers, or at least on mostly white-owned agribusinesses and on their own particular agenda.

With respect to traditional leaders and their allies, my conclusion is that they have been empowered by the way restitution has occurred in Levubu. The leaders of the Ravele 'community' were appointed by the former traditional leader and are now politically close to the current traditional leader. The signs from Mauluma indicate that the Ravele leadership will tightly control the purse strings when revenue from the land begins to flow. Restitution is unlikely to destabilize the colonial present unless, that is, the beneficiaries take control of the Communal Property Association formed in their name and use income from the land to achieve greater financial security and, hence, more independence from the traditional authorities in Mauluma. 
Such a turnabout might be the only way for the 'subjects' in Mauluma to reduce the influence of traditional leaders and autocratic decision-making more generally. I sensed some determination among some people in Mauluma to make such a move, but not from many.

A final issue here connects with both the skills question and the fate of traditional authority. Even if a skills program in the agricultural sector was advanced, there is evidence that (young) Africans' interest in farming the land is dwindling, as Cherryl Walker (2006: 148-9) has discussed. Walker found that young people were reluctant to move from the urban amenities and services in the town of Ladysmith to work on an agricultural project on restituted land in Cremin, KwaZulu-Natal. The reluctance to work in agriculture reflects a broader problem for a land reform program oriented towards commercial agriculture: wages in agriculture cannot compete with the non-agricultural labor market. New policies such as Black Economic Empowerment, via which the government intends the economy to draw skilled black people into the upper ranks of the division of labor (Iheduru 2004), compound the problem. One white farmer in northern Limpopo pointed out the challenge:

There's excellent, excellent people that could do it, that could be trained up. But the market will pull them into wherever they can earn the most. And that won't be agriculture. Not now. Maybe one day, but not now. It will not. It will not pull them in. It’s just not there. Why would a guy who can earn R¹⁄2m [Approx. £35 000] a year go and work for R50 000 a year? He’d be stupid. (Personal interview, October 2004).

Clearly, then, the colonial present will endure if white farmers' monopoly on skills is not diluted. But the question of agriculture's appeal cannot be divorced from the pull of the 'urban' in areas to which African urbanization was historically displaced. The former homeland areas have urban- 
level population densities and, via migration, strong social connections with South Africa's cities. What they lack are urban-type services and jobs.

My research in Mauluma found similar circumstances to Walker’s research in Cremin. Few beneficiaries in Mauluma expressed an interest in permanently moving back to Levubu to live or to farm. In contrast, say, to restitution claims referring to forced removals during the 1960s and 1970s, the length of time since their removal in 1938 has meant that the Ravele restitution beneficiaries have adjusted to life in Mauluma: Mauluma has electricity and most houses are connected to the water supply; and there are social networks of kin and church that would be broken if the beneficiaries moved back to the land. Just as Paula Meth (2001) found in her work on life in Bilanyoni, KwaZulu-Natal, Mauluma has become 'home'; only the very old had any memory of the life they were removed from in Levubu. The beneficiaries' attachment to Mauluma connects with their interest in seeing income from the returned land used to 'develop' Mauluma, that is, to make it more of a town rather than a village; a place with work, roads, shops, clinics. For example, one respondent said, 'I would like a shopping complex. A Spar [shop] perhaps’ (Interview with Respondent \# 13, March 2005). Others said:

'We should develop the schools, improve the standard of the streets, and to tar the road’ (Interview with Respondent \# 2, March 2005)

'It [the money] should be used to develop Mauluma: schools, the clinic, streets and roads’ (Interview with Respondent \# 9, March 2005)

'The money can be used for community development: proper roads and streets' (Interview with Respondent \# 6, March 2005). 
'The priority is roads, a sports facility, a gymnasium and then schools' (Interview with Respondent \# 15, March 2005).

Interest in jobs and services of an urban-type confirmed the declining interest in farming noted by one woman in Mauluma:

'Look at the new generation. How many are doing farming? There is no interest in farming among the young people. Few, very few are interested. There is an irrigation scheme here [in Mauluma] but how many young people are there?’ (Interview with Respondent \# 9, March 2005).

The partnerships operating the Ravele land in Levubu should generate a decent revenue stream but it is unlikely to be enough to transform Mauluma into a town with urban-type services and jobs. Mauluma in unlikely to depart from other areas within the former homelands: it seems likely that the absence of services and jobs will continue to propel young people to drift towards nearby towns or to the main cities. The outcome of this is that the colonial present will be experienced unevenly: wage employment reduces migrants’ material link and dependence upon traditional leaders but without a radical transformation in the government's stance towards traditional leaders, it will be those who are left behind who will continue to live with autocracy, patriarchy, and even (in some cases) despotism; that is, their colonial present will persist.

\section{Acknowledgements}

The Kirwan Institute and Mershon Center at The Ohio State University provided generous funding to carry out the research on which this paper is based. I would like to thank project officers at Nkuzi Development Association, particularly Tshililo Manenzhe, David Kwinda and Shirhami Shirima. Kevin Cox consistently gave insightful advice and comments on the research as a whole as well as various drafts of this paper. Any errors are my responsibility. 


\section{References}

Ashforth, A. (1997) Lineaments of the political geography of state formation in twentieth-century South Africa. Journal of Historical Sociology 10: 101-126.

Beinart, W. (2001) Twentieth-century South Africa. New York: Oxford University Press.

Benjaminsen, T.A., Rohde, R., Sjaastad, E., Wisborg, P. and Lebert, T. (2006) Land reform, range ecology, and carrying capacities in Namaqualand, South Africa. Annals of the Association of American Geographers 96: 524-540.

Benner, C. (2006) 'South Africa on-call': Information technology and labour market restructuring in South African call centres. Regional Studies 40: 1025-1040.

Bernstein, H. (1996) South Africa's agrarian question: Extreme and exceptional? Journal of Peasant Studies 23: 1-52.

Bobrow-Strain, A. (2004) (Dis)Accords: the politics of market-assisted land reforms in Chiapas, Mexico. World Development 32: 887-903.

Bond, P. (2000) Elite transition: from apartheid to neoliberalism in South Africa. London: Pluto Press.

Borras, S. Jr. (2003) Questioning the pro-market critique of state-led agrarian reform. European Journal of Development Research 15: 105-128.

Bundy, C. (1979) The rise and fall of the South African peasantry. London: Heinemann 
Business Day, September 5 2005. Call to get blacks, youth into farming. Accessed via the Internet at <http://www.businessday.co.za/articles/national.aspx?ID=BD4A89481>

Business Day, April 6 2006. Emerging farmers query state policy. Accessed via the Internet at <http://www.businessday.co.za/articles/topstories.aspx?ID=BD4A182062>

Callinicos, L. (1987) A people's history of South Africa. Johannesburg: Raven Press.

Carmody, P. (2002) Between globalisation and (post) apartheid: the political economy of restructuring in South Africa. Journal of Southern African Studies 28: 254-275.

Claassens, A. (2001) 'It is not easy to challenge a chief': Lessons from Rakgwadi. Cape Town: Programme for Land and Agrarian Studies.

Cousins, B. (2006) Agrarian reform and the 'two economies': Transforming South Africa's countryside, in Ntsebeza, L and Hall, R. (2006) The land question in South Africa: The challenge of transformation and redistribution. Cape Town: HSRC Press, pp.220-245.

Crais, C. (2006) Custom and the politics of sovereignty in South Africa. Journal of social history 39: 721-740.

Ettlinger, N. and Bosco, F. (2004) Thinking through networks and their spatiality: A critique of the US (public) War on Terrorism and its geographic discourse. Antipode 36: 249-271. 
Everingham, M. and Jannecke, C. (2006) Land restitution and democratic citizenship in South Africa. Journal of Southern African Studies 32: 543-562.

Fanon, F. (1963) The wretched of the earth. New York: Grove Press. Originally published as Les damne's de la terre. Paris: F. Maspero, 1961.

Fraser, A. (2007) Hybridity emergent: Geo-history, learning, and land restitution in South Africa. Geoforum 38: 299-311.

Fruend, B. (2006) South Africa: A developmental state? Accessed via the Internet December $1^{\text {st }} 2006$ at <http://www.nu.ac.za/ccs/files/Freund\%20Developmental\%20 State.pdf>

Greenberg, S. (2003) Land reform and transition in South Africa. Transformation 52: 4267.

Gregory, D. (2004) The colonial present. Oxford: Blackwell.

Hall, R. (2003) Rural restitution: Evaluating land and agrarian reform in South Africa. Cape Town, South Africa: Programme for Land and Agrarian Studies.

Hall, R. (2004) Land and agrarian reform in South Africa: a status report. Program for Cape Town, South Africa: Programme for Land and Agrarian Studies.

Hall, R. (2006) Transforming rural South Africa? Taking stock of land reform, in Ntsebeza, L and Hall, R. The land question in South Africa: The challenge of transformation and redistribution. Cape Town: HSRC Press, pp. 87-106. 
Harris, C. (2004) How did colonialism dispossess? Comments from an edge of empire. Annals of the Association of American Geographers 94: 165-182.

Hart, G. (2002) Disabling globalization: places of power in post-apartheid South Africa. Berkeley: University of California Press.

Harvey, D. (1985) The geopolitics of capitalism, in Gregory, D. and Urry, J. (eds) Social relations and spatial structures. London: Macmilla, pp. 128-163.

Harvey, D. (2003) The new imperialism. Oxford: Oxford University Press.

Harvey, D. (2005) A brief history of neoliberalism. New York: Oxford University Press.

Iheduru, O.C. (2004) Black economic power and nation-building in post-apartheid South Africa. Journal of Modern African Studies 42: 1-30.

Jacobs, P., Lahiff, E. and Hall, R. (2003) Land redistribution. Cape Town: Programme for Land and Agrarian Studies.

James, D. (2005) Land, popular culture, and the 'broker': how property relationships are mediated in South African land reform. Paper for presentation at 2005 Wits workshop on Law and Society - Orders of Transgression: Law, Crime and Popular Culture in Africa. 
Kepe, T. and Cousins, B. (2002) Radical land reform is key to sustainable rural development in South Africa. Cape Town, South Africa: Programme for Land and Agrarian Studies.

Lahiff, E. (2000) An apartheid oasis?: Agriculture and rural livelihoods in Venda. Portland, OR: Frank Cass.

Lahiff, E. (2005) From 'willing seller, willing buyer' to a people-driven land reform. Cape Town: Programme for Land and Agrarian Studies.

Lodge, T. (2005) Provincial government and state authority in South Africa. Journal of Southern African Studies 31: 737-753.

Mamdani, M. (1996) Citizen and subject: contemporary Africa and the legacy of late colonialism. Princeton, N.J.: Princeton University Press.

Massey, D. (2005) For space. London: Sage.

Mathis, S.M. (2007) The politics of land reform: Tenure and political authority in rural Kwazulu-Natal. Journal of Agrarian Change 7: 99-120.

Mayson, D. (2003) Joint ventures. Cape Town, South Africa: Programme for Land and Agrarian Studies.

Meth, P.J. (2001) Rethinking the dumping grounds: questioning assumptions about movement into the relocation settlement of Bilanyoni. Area 33: 228-241. 
Moyo, S. and Yeros, P. (2005) The resurgence of rural movements under neoliberalism, in Moyo, S. and Yeros, P. (eds.) Reclaiming the land: the resurgence of rural movements in Africa, Asia and Latin America. Zed Books, London, pp. 8-64.

Ntsebeza, L. (2003) Democracy in South Africa’s countryside: Is there a role for traditional authorities? Development Update 4: 53-80.

Ntsebeza, L. and Hall, R. (2006) The land question in South Africa: The challenge of transformation and redistribution. Cape Town: HSRC Press.

Oomen, B. (2005) Chiefs in South Africa: law, power \& culture in the post-apartheid era. Oxford: James Currey.

Peet, R. (2002) Ideology, discourse, and the geography of hegemony: from socialist to neoliberal development in postapartheid South Africa. Antipode 34: 54-84.

Platzky, L. and Walker, C. (1985) The Surplus People. Forced Removals in South Africa. Johannesburg: Ravan Press. 
Ramutsindela, M. (2002) The perfect way to ending a painful past? Makuleke land deal in South Africa, Geoforum 33: 15-24.

Rangan, H. and Gilmartin, M. (2002) Gender, traditional authority and the politics of rural reform in South Africa. Development and Change 33: 633-658.

Said, E. (1978) Orientalism. New York: Pantheon Books.

Shaker, M. (2003) Restructuring of state assets in Limpopo, Service Delivery Review 2: $73-77$.

Walker, C. (2003) Piety in the sky? Gender policy and land reform in South Africa, Journal of Agrarian Change 3: 113-148.

Walker, C. (2005) The limits to land reform: Rethinking 'the land question', Journal of Southern African Studies 31: 805-824.

Walker, C. (2006) Redistributive land reform: For what and for whom?, in Ntsebeza, L and Hall, R. (2006) The land question in South Africa: The challenge of transformation and redistribution. Cape Town: HSRC Press, pp. 132-152.

Wolford, W. (2003) Producing community: the MST and land reform settlements in Brazil. Journal of Agrarian Change 3: 500-520.

Wolford, N. (2005) Agrarian moral economies and neoliberalism in Brazil: competing worldviews and the state in the struggle for land. Environment and Planning A 37: 241261. 


\section{Captions}

Figure One: The northern area of Limpopo Province.

Figure Two: The geographic distribution of Ravele restitution beneficiaries

(Figure Two Source: List of registered Ravele beneficiaries, Ravele Land Claims Committee).

\section{ENDNOTES}

Much more land will have to be redistributed in the next few years to meet the government's target. But the experience of restitution (which was supposed to be completed by 2006 but which is currently intended to end by 2008) suggests that the government is relatively content to move the goal posts when it sees fit.

ii It also would be a mistake to claim that traditional leaders are always a negative influence; negative, that is, in the sense of undermining elected trustees or seeking to secure a disproportionate share of the benefits from restitution. The institution of traditional leadership undoubtedly tends towards denying women their full rights as guaranteed in the Bill of Rights, but project workers in a non-governmental organisation in northern Limpopo drew my attention to one case in which traditional leaders had protected a woman's rights to land after her husband had died and despite his family demanding that she leave his house. 